\title{
The Effect of Growth Conditions on Oxidative and Dehydrogenase Activity in Staphylococcus aureus
}

\author{
By F. M. COLLINS* AND JUNE LASCELLES \\ Microbiology Unit, Department of Biochemistry, University of Oxford
}

(Received 2 March 1962)

\begin{abstract}
SUMMARY
Suspensions of Staphylococcus aureus grown aerobically on nutrient broth oxidized glucose, acetate and intermediates of the tricarboxylic acid cycle, but glucose-grown organisms oxidized glucose only. The inability of glucosegrown staphylococci to oxidize intermediates of the tricarboxylic acid cycle was correlated with diminished succinate and isocitrate dehydrogenase activity in cell-free extracts as compared with extracts from organisms grown without glucose. Suspensions of aerobically-grown staphylococci fermented glucose anaerobically at only about one third the rate observed with anaerobically-grown organisms. The nicotinamide-adenine dinucleotide-linked lactate dehydrogenase activity in extracts of the anaerobicallygrown organisms was about ten times higher than that in extracts of aerobically-grown staphylococci.
\end{abstract}

\section{INTRODUCTION}

Previous work with Staphylococcus aureus showed that suspensions of glucosegrown organisms oxidized glucose to acetate but the latter substance was not metabolized further (Gardner \& Lascelles, 1962). However, there are reports in the literature that suspensions of staphylococci grown in nutrient broth are capable of oxidizing acetate and tricarboxylic acid cycle intermediates although these substrates are not oxidized to completion (Goldschmidt \& Powelson, 1953; Stedman \& Kravitz, 1955). Goldschmidt \& Powelson (1953) also observed that organisms grown with glucose failed to oxidize acetate. In the present work the effect of growth on glucose upon the ability of suspensions to oxidize intermediates of the tricarboxylic acid cycle was examined and the oxidative capacity has been correlated with the degree of activity of certain enzymes of the cycle. The effect of aerobic growth on the ability of suspensions to ferment glucose and upon the activity of lactate dehydrogenase in cell-free extracts was also examined.

\section{METHODS}

Organisms. The parent strain of Staphylococcus aureus (SG511A) was that described previously (Gardner \& Lascelles, 1962). The streptomycin-resistant strain used was isolated following growth of the SG511 A strain on a streptomycin gradient agar plate (Szybalski \& Bryson, 1952); it grew in the presence of streptomycin $200 \mu \mathrm{g} . / \mathrm{ml}$. Stock cultures of both strains were maintained on nutrient agar slopes grown for $18 \mathrm{hr}$. at $37^{\circ}$.

\footnotetext{
* Present address : Department of Microbiology, University of Adelaide, South Australia.
} 
Groweth of organisms and preparation of suspensions. Cultures were grown in Oxoid nutrient broth (Oxoid Ltd. London) supplemented where shown with 0.04 Mglucose (added after autoclaving). Inoculation was with suspensions from nutrient agar slopes, the initial concentration being equivalent to about $0.01 \mathrm{mg}$. dry wt. $/ \mathrm{ml}$. The cultures were grown aerobically on a gyrorotatory shaker or anaerobically in completely filled glass-stoppered bottles. Incubation was at $37^{\circ}$ for $18 \mathrm{hr}$. The organisms were harvested and suspensions prepared as described previously (Gardner \& Lascelles, 1962).

Manometry. Conventional Warburg techniques were used; details of vessel contents and atmosphere are given in the text. Incubation was at $37^{\circ}$.

Preparation of extracts and assay of enzymic activity. The preparation of cell-free extracts, the determination of protein and the assay of lactate dehydrogenase were described previously (Gardner \& Lascelles, 1962). Isocitrate (NADP as acceptor) and succinate dehydrogenase activities were assayed spectrophotometrically by the methods of Ochoa (1955) and Redfearn \& Dixon (1961), respectively. The activity of all three enzymes is expressed as $\mu$ moles substrate oxidized $/ \mathrm{min} . / \mathrm{mg}$. protein. The assays were carried out with an Optica recording spectrophotometer, Model CF 4 DR (Optica Ltd., Gateshead, Co. Durham).

\section{RESULTS}

\section{Effect of glucose on oxidative and enzymic activities}

Oxidative activities of suspensions. Suspensions of the parent strain of Staphylococcus aureus grown aerobically in broth without glucose consumed oxygen in the presence of glucose, acetate or dicarboxylic acids at rates in excess of that observed without substrate (Table 1). In contrast, organisms grown with glucose did not oxidize acetate or the dicarboxylic acids, though the rate of oxygen uptake with glucose was similar to that of organisms grown without this sugar (Table 1).

The effect of growth with glucose on the respiratory activity might have been due $(a)$ to acid production which impaired the ability of organisms to oxidize sub-

Table 1. Oxidation of substrates by a streptomycin-sensitive and a streptomycinresistant strain of Staphylococcus aureus grown without and with glucose

The organisms were harvested after $18 \mathrm{hr}$. aerobic incubation in broth, supplemented where shown with $0.04 \mathrm{~m}$-glucose. Suspensions were incubated in air at $37^{\circ}$ in Warburg vessels containing: organisms, equiv. 2.5-5.0 mg. dry wt.; potassium phosphate buffer (pH 7.4) $250 \mu$ moles; substrate (added from side arm at zero) $40 \mu$ moles; water to $2.5 \mathrm{ml}$. The centre wells contained $0.2 \mathrm{ml} .5 \mathrm{~N}-\mathrm{NaOH}$. The sodium salts of the organic acids were used. The $Q_{\mathrm{O}_{2}}$ values are calculated from the rates observed during the first $30 \mathrm{~min}$. incubation, after subtraction of the endogenous value.

\begin{tabular}{|c|c|c|c|c|}
\hline \multirow[b]{3}{*}{ Substrate } & \multicolumn{2}{|c|}{ Parent strain grown } & \multicolumn{2}{|c|}{$\begin{array}{l}\text { Streptomycin-resistant } \\
\text { strain grown }\end{array}$} \\
\hline & $\begin{array}{l}\text { Without } \\
\text { glucose }\end{array}$ & $\begin{array}{l}\text { With } \\
\text { glucose }\end{array}$ & $\begin{array}{l}\text { Without } \\
\text { glucose }\end{array}$ & $\begin{array}{l}\text { With } \\
\text { glucose }\end{array}$ \\
\hline & \multicolumn{4}{|c|}{$Q_{\mathrm{O}_{2}}$ values } \\
\hline Nil & 16 & 8 & 20 & 10 \\
\hline Glucose & 52 & 47 & 49 & 40 \\
\hline Acetate & 13 & 0 & $\mathbf{3}$ & $\mathbf{0}$ \\
\hline Succinate & 39 & $\mathbf{0}$ & 17 & 0 \\
\hline Malate & 28 & 0 & 7 & 0 \\
\hline
\end{tabular}


strates other than glucose, or $(b)$ to a faster growth rate with glucose present resulting in the organisms being physiologically 'aged' at harvest. These possibilities were eliminated by testing the activity of organisms grown in glucose broth buffered with 0.04 M-potassium phosphate ( $\mathrm{pH} \mathrm{7 \cdot 4)}$ ) and harvested during the exponential phase of growth; the culture at harvest was at $\mathrm{pH} 7 \cdot 1$. Such organisms again showed no ability to oxidize substrates other than glucose.

The streptomycin-resistant strain behaved qualitatively in the same way as the parent organism, but when grown without glucose it oxidized acetate and the dicarboxylic acids less actively, though the $Q_{0_{2}}$ with glucose as substrate was similar to the parent (Table 1). Growth with glucose completely suppressed the ability to oxidize all substrates except glucose.

Suspensions of the parent-strain grown on galactose behaved similarly to those grown on glucose. The situation in Staphylococcus aureus differs, therefore, from that in Saccharomyces cerevisiae which exhibits enhanced oxidative activity when grown on galactose instead of glucose (Strittmatter, 1957).

Activity of succinate and isocitrate dehydrogenases in cell-free extracts. The inability of glucose-grown organisms to oxidize acetate and intermediates of the tricarboxylic acid cycle suggested that one or more enzymes of this sequence might be lacking. Assay of two enzymes of the cycle, namely succinate and isocitrate dehydrogenases, showed them to be present in extracts from organisms grown aerobically without glucose; but in extracts from glucose-grown organisms isocitrate dehydrogenase was not detected and the activity of succinate dehydrogenase was considerably decreased (Table 2). Lactate dehydrogenase activity was not influenced by growth with glucose. The enzymic activities in extracts of the streptomycin-resistant staphylococcus were similar to those of the parent grown under comparable conditions ('Table 2).

Table 2. Succinate and isocitrate dehydrogenase in extracts of staphylococci

Dehydrogenase activity was assayed as described in the Methods section in extracts prepared from organisms grown aerobically on nutrient broth alone or with $0.04 \mathrm{M}$ glucose. Results are expressed as units of enzyme/mg. protein and are the mean of at least three determinations with different extracts showing less than $20 \%$ variation.

\begin{tabular}{|c|c|c|c|c|}
\hline & Glucose in & $\begin{array}{c}\text { Succinate } \\
\text { dehydrogenase } \\
\text { Units }\end{array}$ & $\begin{array}{c}\text { Isocitrate } \\
\text { dehydrogenase } \\
\text { of enzyme/mg. }\end{array}$ & $\begin{array}{c}\text { Lactate } \\
\text { dehydrogenase } \\
\text { cotein }\end{array}$ \\
\hline Strain & growth medium & 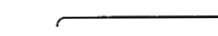 & & \\
\hline Parent & $\bar{t}$ & $\begin{array}{l}0.13 \\
0.02\end{array}$ & $\begin{array}{r}0.16 \\
<0.01\end{array}$ & $\begin{array}{l}0 \cdot 92 \\
0 \cdot 68\end{array}$ \\
\hline Streptomycin-resistant & $\overline{+}$ & $\begin{array}{l}0 \cdot 09 \\
0 \cdot 02\end{array}$ & $\begin{array}{r}0.15 \\
<0.01\end{array}$ & - $^{*}$ \\
\hline
\end{tabular}

Effect of growth under aerobic and anaerobic conditions on the fermentation of glucose and on lactate dehydrogenase activity

Suspensions of the parent staphylococcus grown aerobically with glucose, fermented glucose anaerobically at only about $30 \%$ of the rate observed with organisms grown anaerobically (Table 3). In these experiments acid production from glucose 
in a bicarbonate $+\mathrm{CO}_{2}$ buffer was taken as an index of fermentative activity. Previous work had shown that lactic acid was the main end-product of glucose fermentation by this organism (Gardner \& Lascelles, 1962).

Assay of lactate dehydrogenase in extracts of organisms grown aerobically and anaerobically showed that this activity was about ten times higher in preparations from anaerobically-grown staphylococci (Table 3); the enzyme was specific for the $\mathrm{L}(+)$ isomer. Thus, there was a correlation between the rate of glucose fermentation and lactate dehydrogenase activity.

\title{
Table 3. Fermentation and lactic dehydrogenase activity of staphylococci grown aerobically and anaerobically
}

\begin{abstract}
The parent strain Staphylococcus aureus (SG511 A) was grown aerobically or anaerobically in nutrient broth $+0.04 \mathrm{~m}$ glucose. Fermentation by washed organisms was followed in manometric vessels containing: organisms, equiv. $2.5-5 \mathrm{mg}$. dry wt.; $\mathrm{NaHCO}_{3}$, $25 \mu$ moles; glucose (added from side arm at zero), $100 \mu$ moles; water to $2 \cdot 5 \mathrm{ml}$; $\mathbf{p H ~} \mathbf{7 \cdot 6}$. Incubation was in an atmosphere of $5 \% \mathrm{CO}_{2}$ in $\mathrm{N}_{2}$ at $37^{\circ}$. The results are the mean of three experiments, the results differing by less than $10 \%$. No correction made for acid production without glucose as this was negligible. Results are expressed as $\mu \mathrm{l} . \mathrm{CO}_{2}$ liberated $/ \mathrm{hr} . / \mathrm{mg}$. dry wt. organism. Lactate dehydrogenase was measured in extracts as described in the Methods section. The results are the mean of at least three assays with different extracts, showing less than $20 \%$ variation.
\end{abstract}

$\begin{array}{lcc}\begin{array}{c}\text { Growth } \\ \text { conditions }\end{array} & \begin{array}{c}\text { Fermentation } \\ \text { of glucose } \\ \left(Q_{\mathrm{CO}_{2}}\right)\end{array} & \begin{array}{c}\text { dehydrogenase } \\ \text { (units/mg. } \\ \text { protein) }\end{array} \\ \text { Aerobic } & 35 & 0 \cdot 58 \\ \text { Anaerobic } & 119 & 4.6\end{array}$

\section{DISCUSSION}

There are many examples in the literature of repression of enzyme synthesis by glucose. In particular, the presence of glucose prevents the formation of inducible enzymes necessary for the utilization of alternative energy sources (Magasanik, Magasanik \& Neidhardt, 1959; Mandelstam, 1961). The results presented here suggest that in Staphylococcus aureus glucose represses the development of some of the enzymes of the tricarboxylic acid cycle. Since staphylococci are normally grown on complex media containing preformed amino acids the cycle is not required to provide precursors of these essential metabolites. When glucose is also provided, sufficient energy for growth is presumably gained by incomplete oxidation of the sugar to the acetate stage, and the operation of the cycle is again not necessary. In the absence of glucose the energy requirements of the organism are probably satisfied by oxidation of amino acids via mechanisms which probably involve the tricarboxylic acid cycle.

Lactic acid is the main end-product of glucose fermentation in anaerobically grown Staphylococcus aureus (Gardner \& Lascelles, 1962). Thus the main outlet for substrate hydrogen is by reduction of pyruvate mediated by the NAD-linked lactate dehydrogenase. The importance of this enzyme in the anaerobic energy-yielding mechanism of the organism is stressed by the observation that it is about ten times more active in organisms grown anaerobically than in those grown aerobically. Also, there is a correlation between the activity of this enzyme and the ability of suspensions to ferment glucose; when grown aerobically, the organisms are low both in 
lactate dehydrogenase and in fermentative activities as compared to the anaerobically-grown organisms. The importance of another NAD-linked enzyme, alcohol dehydrogenase, in anaerobic metabolism has been suggested by the observation that this enzyme is ten to twenty times more active in Aerobacter aerogenes grown anaerobically on glycerol than when it is grown aerobically (McPhedran, Sommer \& Lin, 1961).

This work was aided by grants to the Department from the Rockefeller Foundation and from the United States Department of Health, Education and Welfare.

\section{REFERENCES}

GARDNER, J. F. \& LASCELLES, J. (1962). The requirement for acetate of a streptomycinresistant strain of Staphylococcus aureus. J. gen. Microbiol. 29, 157.

Goldschmidt, M. C. \& Powelson, D. M. (1953). Effect of the culture medium on the oxidation of acetate by Micrococcus pyogenes var. aureus. Arch. Biochem. Biophys. 46, 154.

Magasanik, B., Magasanik, A. K. \& Neidhardt, F. C. (1959). In The Regulation of Cell Metabolism, p. 334. Ed. by G. E. W. Wolstenholme \& C. M. O'Connor. London: J. and A. Churchill Ltd.

MANDELSTAM, J. (1961). Induction and repression of $\beta$-galactosidase in non-growing Escherichia coli. Biochem. J. 79, 489.

McPhedran, P., Sommer, B. \& Lin, E. C. C. (1961). Control of ethanol dehydrogenase levels in Aerobacter aerogenes. J. Bact. 81, 852.

Oснод, S. (1955). In Methods in Enzymology, 1, 699. Ed. by S. P. Colowick \& N. O. Kaplan. New York: Academic Press Inc.

Redfearn, E. R. \& Dixon, J. M. (1961). Spectrophotometric methods for the determination of succinic-dehydrogenase and succinic-oxidase activities in mitochondrial preparations. Biochem. J. 81, 19 P.

Stedman, R. L. \& Kravitz, E. (1955). Evidence for a common pathway for pyruvate and acetate oxidation by Micrococcus pyogenes var. aureus. Arch. Biochem. Biophys. 59, 260.

Strittmatter, C. F. (1957). Adaptive variation in the level of oxidative activity in Saccharomyces cerevisiae. J. gen. Microbiol. 16, 169.

Szybalski, W. \& Bryson, V. (1952). Genetic studies on microbial cross resistance to toxic agents. I. Cross resistance of Escherichia coli to fifteen antibiotics. J. Bact. 64, 489. 